\title{
BOBOT BADAN DAN PERTAMBAHAN BOBOT BADAN AYAM KAMPUNG PERIODE STARTER PADA KETINGGIAN TEMPAT BERBEDA
}

\author{
THE EFFECT OF ATTITUDE ON BODY WEIGHT AND AVERAGE DAILY GAIN OF NATIVE \\ FOWL AT STARTER PERIOD \\ Rajab; \\ Jurusan Peternakan, Fakultas Pertanian, Universitas Pattimura \\ Jln. Ir. M. Putuhena, Kampus Poka - Ambon, Kode Pos. 97233 \\ Email : rajab.amir@gmail.com

\begin{tabular}{|l|l}
\hline Diterima: 25 Februari 2019 & Disetujui: 10 Maret 2019
\end{tabular}

\begin{abstract}
Abstrak
Faktor lingkungan fisik seperti kondisi iklim dan ketinggian tempat memiliki pengaruh yang tidak kalah pentingnya terhadap performa produksi ternak ayam. Penelitian ini dilakukan bertujuan untuk mengetahui perfoma ayam kampung periode starter yang dipelihara pada lokasi dengan ketinggian tempat yang berbeda. Total sebanyak 106 ekor ayam kampung (64 ekor ayam pada dataran tinggi (Waringin Cap) dan 42 ekor ayam pada dataran rendah (Air Alii)) dipelihara secara intensif. Ayam ditempatkan dalam kandang brooder berukuran 2 x 1 x 1 meter, dan diberi pakan komersial Br-E21 produksi PT. JAPFA COMFEED dan air minum yang dicampur dengan VITA-CHICK. Peubah yang diamati yaitu bobot badan dan pertambahan bobot badan, dimana ayam ditimbang setiap minggu selama 4 minggu. Hasil penelitian menunjukkan bahwa ayam di Waringin Cap memiliki bobot badan sebesar 30,70 ; 46,48; 131,44; 248,44 dan 329,98 gram sedangan bobot badan ayam di Air Alii sebesar 30,98; 47,34; 139,45; 254,21 dan 348,81 gram masing-masing untuk ayam umur 1 hari, 1, 2, 3 dan 4 minggu. Rataan pertambahan bobot badan ayam kampung periode starter berkisar antara 0,22 - 0,40 dan 0,32 - 0,52 gr/ekor/hari masing-masing untuk lokasi dataran tinggi dan dataran rendah, namun pengaruh perbedaan ketinggian tempat tidak signifikan terhadap performa ayam kampung ayam kampung periode starter yang dipelihara secara intensif.
\end{abstract}

Kata kunci: Bobot badan, pertambahan bobot badan, ayam Kampung.

\begin{abstract}
Phisical environment such as climate and attitude of place were the important factors effect on production performance of broiler, layer, or domectic fowl. The purpose of this research was to know the effect of altitude on body weight and average daily gain of native fowl breeded at starter period. The research was conducted at Waringin Cap area (highland of attitude place) and Air Alii Area (lowland of attitude place), which 106 tail of native fowl were rearing in intersive poultry farming system. DOC were placed on brooder box cage with 2 x 1 x 1 of size. The variables such as body weight and average daily gain were measured every week during 4 week observation. The results of this study show that both the average of body weight of hen in Waringin Cap were 30,$70 ; 46,48 ; 131,44 ; 248,44$ dan 329,98 g, whereas the average of body weight of hen in Air Alii were 30,98; 47,34; 139,45; 254,21 dan 348,81 g respectively for one day, $1,2,3$, and 4 weeks of age. The average daily gain rate were $0,22-0,40$ and $0,32-0,52$ $\mathrm{g} /$ tail/day respectively for chicken in highland and lowland attitude rearing. and there are no significantly different of the attitude effect on native fowl performance breeded at starter period.
\end{abstract}

Keywords: Body weight, average daily gain, native fowl.

DOI: 10.30598.jhppk. 2019.3.1.107

ISSN ONLINE: 2621-8798

Page 107 


\section{PENDAHULUAN}

Keunggulan ayam Kampung diantaranya yaitu mempunyai produksi daging dengan rasa dan tekstur yang khas, dan khasiat telur yang spesifik, selain itu ayam ini tahan terhadap beberapa jenis penyakit. Ayam kampung mudah dikenali karena banyak berkeliaran di desa-desa hampir di seluruh wilayah Indonesia. Keanekaragaman performa ayam kampung dalam satu wilayah masih sangat besar dan bervariasi seperti dalam hal wama bulu, bobot badan, pertumbuhan dan produksi telur (Sartika dan Iskandar, 2007). Performa ternak seperti halnya ayam kampung yang sangat bervariasi selain disebabkan oleh variasi pada faktor kebakaan atau genetik yang berasal dari dalam (faktor internal), juga karena adanya variasi faktor lingkungan dimana ayam tersebut dipelihara (Wiener, 1999).

Selain faktor pakan yang berkontribusi terhadap hampir $70 \%$ biaya produksi pada usaha peternakan, faktor lingkungan fisik seperti kondisi iklim dan topografi wilayah atau ketinggian tempat juga memiliki pengaruh yang tidak kalah pentingnya terhadap performa produksi ternak yang dipelihara. Kenaikan tempat dari permukaan laut selalu diikuti dengan penurunan suhu rata-rata harian. Perbedaan geografis seperti perbedaan ketinggian tempat di atas permukaan laut (dpl) akan menimbulkan perbedaan cuaca dan iklim mikro secara keseluruhan pada tempat tersebut, terutama suhu dan kelembaban (Andrian et al., 2014). Suhu di permukaan bumi makin rendah dengan bertambahnya lintang, seperti halnya penurunan suhu menurut ketinggian. Makin tinggi tempat maka suhunya makin rendah dan kelembaban akan makin tinggi. Pada tempat yang semakin tinggi dari atas permukaan laut suhu udaranya semakin rendah, sehingga ternak akan mengkonsumsi ransum lebih banyak untuk memenuhi kebutuhan akan energinya. Pada suhu yang lebih rendah daripada kebutuhan optimumnya, ternak akan mengkonsumsi ransum lebih banyak karena sebagian energi ransum akan diubah menjadi panas untuk mengatasi suhu lingkungan yang lebih rendah (Leeson, 1986).

Pengaruh ketinggian tempat dari permukaan laut seperti halnya pengaturan suhu di laboratorium secara signifikan berpengaruh terhadap performa ayam yang dipelihara yang diukur melalui laju pertumbuhan, konsumsi aur, konsumsi ransum dan konversi gizinya. Pengaruh ketinggian tempat nyata terhadap pertumbuhan ayam pada periode umur lima minggu ke atas dalam kondisi temperature bebas, namun tidak nyata terhadap pertumbuhan ayam periode starter (umur 4 minggu ke bawah) yang pemeliharaannya masih dalam kotak pemanas (brooder). Selanjutnya secara khusus perbedaan tinggi 
tempat memberikan pengaruh yang sangat nyata lebih menguntungkan terhadap performa ayam pedaging (broiler) di dataran tinggi daripada yang dipelihara di datarn rendah (Soeharsono, 1976 dalam

\section{METODE PENELITIAN}

Penelitian lapangan dilakukan pada lokasi usaha peternakan ayam kampung yang memiliki ketinggian tempat yang berbeda yaitu (1) usaha peternakan di Dusun Waringin Cap (memiliki ketinggian tempat lebih dari 250 meter dpl) dan (2) usaha ayam Kampung di Dusun Air Alii Desa Rumah Tiga (terletak pada ketinggian tempat kurang dari 100 meter dpl). Soribasya (1980) dalam Suarjaya dan Nuriyasa (2015) memberikan batasan bahwa daerah dataran rendah ketinggian tempatnya berkisar antara $0-250$ meter dari permukaan laut (dpl) dan daerah dataran sedang berkisar antara 250 - 750 meter dpl. Penelitian berlangsung selama 3 (tiga) bulan.

Materi dalam penelitian ini adalah 106 ekor ayam kampung (masing-masing 64 dan 42 ekor pada dusun Waringin Cap dan Taeno Atas) yang dipelihara secara intensif mulai dari day old chick (DOC) sampai umur 4 minggu yang merupakan periode fase starter. DOC ayam Kampung diperoleh melalui penetasan secara alami dalam waktu yang bersamaan. Peralatan yang digunakan antara lain kandang
Adiwinarto, 2005). Penelitian ini dilakukan bertujuan untuk mengetahui perfoma ayam kampung periode starter (umur 0-4 minggu) yang dipelihara pada lokasi dengan ketinggian tempat yang berbeda

brooder berbentuk kotak berukuran $2 \mathrm{~m}$ x 1 $\mathrm{m} \times 1 \mathrm{~m}$, tempat pakan dan minum masingmasing sebanyak 4 buah, lampu pijar 60 watt sebanyak 2 buah, timbangan digital merk "KRISBOW kapasitas $5 \mathrm{~kg}$ dengan tingkat ketelitian $1 \mathrm{~g}$ untuk menimbang pakan dan mengukur bobot badan ayam, alat tulis dan kamera untuk dokumentasi, serta peralatan lain yang diperlukan.

Prosedur penelitian dimulai dengan tahap persiapan dilakukan sebelum DOC mulai dipelihara meliputi membersihkan kandang, tempat pakan, dan tempat minum yang digunakan. Pembersihan ini dilakukan 1 minggu sebelum ayam masuk ke kandang. Lantai dan dinding kandang yang telah dibersihkan, diberi kapur $\left(\mathrm{CaCO}_{3}\right)$ untuk pencegahan penyakit. Lantai kandang dilapisi dengan sekam kering dan disemprot dengan disinfektan. Setelah DOC masuk, pertama kali diberi air gula untuk mencegah stress dan beberapa saat kemudian baru diberi makan. Pakan yang diberikan berupa pakan komersial merk "Br-21E" produksi PT. JAPFA COMFEED. Pakan akan ditimbang dan dicatat setiap kali pemberian, demikian pula sisa pakan untuk mengetahui jumlah konsumsi pakan. Selama 
pemeliharaan air minum yang dicampur dengan VITA-CHICK diberikan secara $a d$ libitum. Kandang beserta peralatannya dibersihkan secara rutin, kelembaban litter diperiksa secara rutin untuk diganti dengan yang baru, demikian pula pemeriksaan terhadap ayam yang menunjukkan gejala sakit.

Pengumpulan data dilakukan dengan metode survey observasi dan percobaan/pengukuran. Peubah yang diamati dalam penelitian ini adalah perfoma ayam kampung terdiri atas bobot badan (diukur dengan timbangan dalam satuan gram) dan pertambahan bobot badan

\section{HASIL DAN PEMBAHASAN}

\section{Bobot Badan Ayam Kampung Periode Starter}

Bobot badan ayam kampung periode starter (umur 1 hari sampai 4 minggu) yang dipelihara pada lokasi dengan ketinggian tempat yang berbeda dalam penelitian ini seperti tertera pada tabel 1. Hasil penelitian menunjukkan bahwa secara umum bobot badan ayam kampung yang dipelihara di daerah dataran rendah (Air Alii) cenderung memiliki bobot badan lebih tinggi dibanding ayam yang (merupakan selisih bobot akhir dengan bobot awal dalam periode waktu tertentu, dalam satuan gram/ekor/hari) yang dilakukan setiap minggu.

Deskripsi terhadap bobot badan dan pertambahan bobot badan ayam dianalisis dengan menggunakan nilai rataan, simpangan baku, dan koefisien keragaman. Guna mengetahui perbedaan performa ayam kampung pada ketinggian tempat yang berbeda dilakukan analisis menggunakan uji t. Prosedur analisis menggunakan software statistik MINITAB versi 17.0.

berada di Waringin Cap (dataran tinggi). Meski demikian berdasarkan hasil uji t, tidak terdapat perbedaan bobot badan yang signifikan antara kedua lokasi tersebut (P value $>0,05$ ). Pada umur 1 hari selisih bobot badan antara kedua lokasi sebesar 0,27 gram, dan meningkat menjadi 18,83 gram pada umur 4 minggu. Hal ini menunjukkan bahwa bobot badan ayam kampung di dataran rendah memiliki kecepatan pertumbuhan yang lebih cepat dibandingkan pada daerah dataran tinggi.

Tabel 1. Rataan \pm simpangan baku bobot badan ayam kampung periode starter

\begin{tabular}{lccccc}
\hline \multirow{2}{*}{ Lokasi } & \multicolumn{5}{c}{ Bobot Badan Menurut Umur (gr) } \\
\cline { 2 - 6 } & DOC $^{\text {TN })}$ & 1 Minggu $^{\text {TN })}$ & 2 Minggu $^{\text {TN }}$ & 3 Minggu $^{\text {TN }}$ & 4 Minggu $^{\text {TN }}$ \\
\hline Warcap & $30,70 \pm 3,69$ & $46,48 \pm 4,99$ & $131,44 \pm 37,66$ & $248,44 \pm 37,22$ & $329,98 \pm 56,12$ \\
Air Alii & $30,98 \pm 3,92$ & $47,34 \pm 4,68$ & $139,95 \pm 37,67$ & $254,21 \pm 36,40$ & $348,81 \pm 54,90$ \\
\hline Keterangan: TN) : tidak berbeda nyata $(P>0,05)$ & & & \\
\hline \hline & DOI: 10.30598/jhppk. 2019.3.1.107 & Page 110
\end{tabular}


Perbedaan ketinggian tempat yang berdampak terhadap perbedaan suhu, dimana suhu yang tinggi dapat memberikan pengaruh negatif terhadap performa produksi ayam, baik ayam kampung maupun ayam ras. Hal ini sejalan dengan Nataamijaya dkk. (1990) kemudian melakukan penelitian pengaruh suhu lingkungan pada ayam buras dengan cara menempatkan ayam buras di dataran rendah (suhu lingkungan tinggi) dan di dataran tinggi (suhu lingkungan rendah). Hasilnya terdapat perbedaan performa produksi dalam hal ini produksi telur, dimana ayam di dataran tinggi memiliki $25 \%$ produktifitas lebih rendah dibanding ayam pada dataran rendah. Menurut Bird et al. (2003) dalam Gunawan dan Sihombing (2004) suhu lingkungan tinggi dapat menurunkan produktifitas ternak seperti produksi telur. Pada suhu lingkungan tinggi diperlukan energi lebih banyak untuk pengaturan - suhu tubuh, sehingga mengurangi penyediaan energi untuk peningkatan bobot badan maupun produksi telur. Pada suhu lingkungan tinggi konsumsi pakan turun, ini berarti berkurangnya nutrisi dalam tubuh, dan akhirnya menurunkan performa produksi.

Hasil uji statistik menunjukkan tidak terdapat perbedaan bobot badan ayam kampung baik di dataran rendah maupun dataran tinggi baik saat masih DOC maupun sampai dengan umur 4 minggu.
Hal ini disebabkan pada periode starter ayam masih berada dalam kandang pemanas (brooder) yang disiapkan oleh peternak, dan brooder juga ditempatkan dalam kandang tertutup, sehingga cekaman pengaruh suhu lingkungan dari luar kandang sangat kecil. Hal ini sejalan dengan pendapat Soeharsono (1976) dalam Adiwinarto (2005) dimana pengaruh ketinggian tempat nyata terhadap pertumbuhan ayam pada periode umur lima minggu ke atas dalam kondisi temperature bebas, namun tidak nyata terhadap pertumbuhan ayam periode starter (umur 4 minggu ke bawah) yang pemeliharaannya masih dalam kotak pemanas (brooder).

\section{Pertambahan Bobot Badan Ayam Kampung Periode Starter}

Pertambahan bobot badan (PBB) ayam kampung yang dipelihara pada umur 1 hari sampai dengan 4 minggu dari lokasi dengan ketinggian tempat berbeda seperti tertera pada gambar 1. Hasil penelitian menunjukkan bahwa ayam di dataran rendah (Air Alii) memiliki pertambahan bobot badan lebih tinggi dibandingkan ayam pada daerah dataran tinggi (Waringin Cap), disamping itu trend pertambahan bobot badan ayam di dataran rendah cenderung meningkat dari minggu I sampai IV. Menurut Nataamijaya dkk. (1990) bahwa terdapat perbedaan pertumbuhan ayam buras antara ayam dataran rendah dan 
dataran tinggi, yang disebabkan oleh perbedaan konsumsi pakan dan karena serangan penyakit (CRD, koksidiosis dan cacingan) . Penurunan konsumsi pakan ini merupakan suatu reaksi fisiologis tubuh untuk mengurangi beban panas yang ditimbulkan oleh proses pencernaan pakan (heat increment). Sebagai perbandingan, digunakan data pertumbuhan bobot badan ayam ras pedaging yang dipelihara pada suhu lingkungan $25-35^{\circ} \mathrm{C}$ adalah $17 \%$ lebih rendah dibandingkan dengan yang dipelihara pada suhu lingkungan 18-250C (Sinurat, 1986 dalam Gunawan dan Sihombing, 2004).

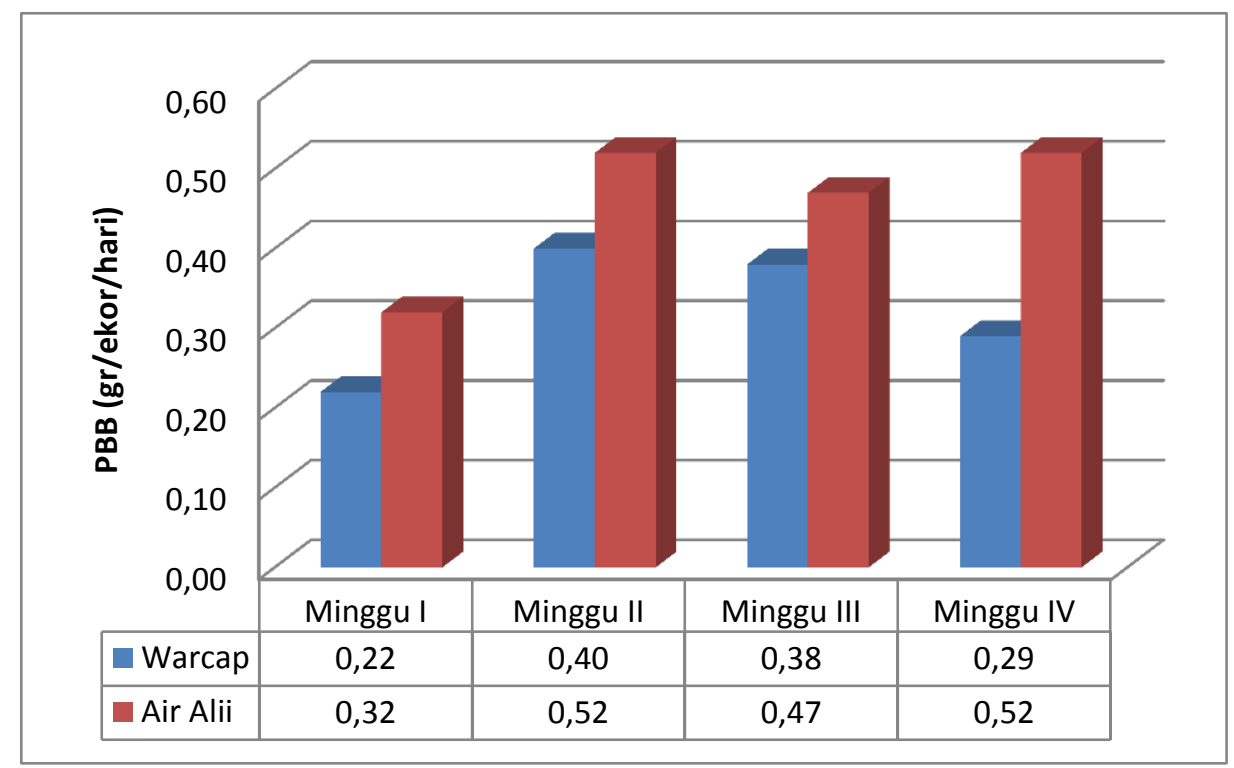

Gambar 1. Pertambahan bobot badan ayam kampung periode starter

Hasil analisis statistik menunjukkan tidak terdapat perbedaan pertambahan bobot badan ayam kampung periode starter antara usaha peternakan di dataran tinggi dengan dataran rendah, yang diakibatkan oleh penggunaan brooder. Sehingga sistem pemeliharan intensif dapat digunakan untuk mengurangi pengaruh mikroklimat seperti suhu yang tinggi terhadap perfoma produksi ayam kampung. Menurut Gunawan dan Sihombing (2004) ada empat upaya yang dapat dilakukan peternak untuk meningkatkan produktivitas ayam di daerah bersuhu lingkungan tinggi (panas), yaitu: seleksi dan perkawinan silang, modifikasi atau manipulasi iklim mikro, penyesuaian tata laksana pemeliharaan dan manipulasi zat gizi pakan, di mana keempat hal ini hanya dapat dilakukan melalui aplikasi sistem pemeliharaan secara intensif. 
KESIMPULAN DAN SARAN

Kesimpulan

Rataan pertambahan bobot badan ayam kampung periode starter berkisar antara $0,22-0,40$ dan $0,32-0,52$ gr/ekor/hari

\section{DAFTAR PUSTAKA}

Adiwinarto G., 2005. Penampilan dan laju pertumbuhan relative karkas dan komponen karkas dua strain ayam broiler fase finisher (21-42 hari) dalam berbagai suhu pemeliharan. Tesis. Program pasca sarjana Universitas Dipenogoro. Semarang.

Andrian S., dan M. Purba. 2014. Pengaruh ketinggian tempat dan kemiringan lereng terhadap produksi karet (Hevea brasiliensis Muell. Arg.) di kebun Hasepong PTPN III Tapanuli Selatan. Jurnal Online Agroteknologi 3(2): 981 - 989.

Gunawan, dan D.T.H. Sihombing. 2004. Pengaruh suhu lingkungan tinggi terhadap kondisi Fisiologis dan produktivitas ayam buras. WARTAZOA. 14(1): 31-38.

Leeson, S. 1986. Nutritional Considerations of Poultry During Heat Stress. Poult. Sci. 42: 69-81.

Nataamijaya A.G., H. Resnawati, T. Antawijaya, I. Barchia dan D. Zainuddin. 1990. Produktivitas ayam buras di dataran tinggi dan dataran rendah. Jurnal Ilmu dan Peternakan Balitnak, Bogor. 4(3): 30-38.

Sartika T., dan S. Iskandar. 2007. Mengenal Plasma Nutfah Ayam masing-masing untuk lokasi dataran tinggi dan dataran rendah, namun pengaruh perbedaan ketinggian tempat tidak signifikan terhadap performa ayam kampung ayam kampung periode star.

Indonesia dan Pemanfaatannya. Bogor: Balai Penelitian Ternak Puslitbangnak.

Suarjaya M., dan M. Nuriyasa. 2015. Pengaruh ketinggian tempat (altitude) dan tingkat energy Ransum terhadap penampilan ayam buras super umur $2-7$ Minggu.

http://www.media.penelitian.co. Diakses 04 Januari 2018.

Wiener G. 1999. Animal Breeding: Center for Tropical Veterinary Medicine. First Published. London: University of Edinburg, Mac Millan Education Ltd. 